\title{
Commercial real estate and equity market bubbles: are they contagious to REITs?
}

Article

Nneji, O., Brooks, C. and Ward, C. (2013) Commercial real estate and equity market bubbles: are they contagious to REITs? Urban Studies, 50 (12). pp. 2496-2516. ISSN 1360063X doi: https://doi.org/10.1177/0042098013477700 Available at https://centaur.reading.ac.uk/31494/

It is advisable to refer to the publisher's version if you intend to cite from the work. See Guidance on citing.

To link to this article DOI: http://dx.doi.org/10.1177/0042098013477700

Publisher: Sage

All outputs in CentAUR are protected by Intellectual Property Rights law, including copyright law. Copyright and IPR is retained by the creators or other copyright holders. Terms and conditions for use of this material are defined in the End User Agreement.

\section{www.reading.ac.uk/centaur}

\section{CentAUR}

Central Archive at the University of Reading

Reading's research outputs online 
This is the authors' accepted manuscript (post-peer review but precopyediting) of an article published in Urban Studies. The definitive version is available at: http://usj.sagepub.com/content/50/12/2496.full or via DOI: $10.1177 / 0042098013477700$ 


\title{
Commercial real estate and equity market bubbles: Are they contagious to REITs?
}

\author{
Ogonna Nneji \\ ICMA Centre, University of Reading \\ Chris Brooks \\ ICMA Centre, University of Reading \\ Charles Ward \\ ICMA Centre, University of Reading
}

August 2012

\begin{abstract}
This paper uses a regime switching approach to determine whether prices in the stock, direct real estate and indirect real estate markets are driven by the presence of speculative bubbles. The results show significant evidence of the existence of periodically partially collapsing speculative bubbles in all three markets. We then develop and implement a multivariate bubble model to evaluate whether the stock and real estate bubbles spill over into REITs. We find the underlying stock market bubble to be a stronger influence on the securitized real estate market bubble than that of the property market. Furthermore, our findings suggest a transmission of speculative bubbles from the direct real estate to the stock market, although this link is not present for the returns themselves.
\end{abstract}

Key words: periodically collapsing speculative bubbles, spillovers, contagion, REITs, real estate 


\section{Introduction}

Formally authorized by Congress in 1960, Real Estate Investment Trusts (REITs, which are also referred to as securitized, indirect or public real estate) are exchange-listed closed-end investment firms that offer investors the opportunity to gain indirect exposure to the real estate market. Since the introduction of REITs, there has been a series of favorable structural reforms in the regulations guiding them. ${ }^{1}$ One consequence of the regulatory changes was a surge in initial public offerings (IPO) in the mid-1990s that prompted the interest of academic and industry researchers. But what factors drive changes in the prices of REITs? While some studies have investigated the relative influence of the equity market and the private real estate market on the behavior of REIT prices, the conclusions of these papers are far from being cohesive.

One stream of literature essentially concludes that the indirect real estate market is related and more sensitive to changes in the stock market than the underlying unsecuritized real estate market. Goetzmann and Ibbotson (1990) is one of the earliest papers to study the relationship between the markets for the period 1972 - 1989. They find REIT returns to be more correlated with the equity market than with the direct property market, concluding that REITs are not close substitutes for the unsecuritized real estate market. Similarly, Seiler et al. (1999) find that returns to the direct and indirect real estate markets differ from one another. Glascock et al. (2000), who control for the structural change of the REIT market in 1992, find that the returns from equity REITs are more closely related to the returns from stocks post-1992 than to the returns from the private ("direct") real estate market.

A second stream of literature, however, makes opposing inferences of the relationship, generally finding a linkage between the direct and securitized real estate markets. Regressing the returns on both the Russell-NCREIF index and the NAREIT Equity REIT index on stock and bond markets' returns separately, Giliberto (1990) finds the regression errors to be correlated and concludes that

\footnotetext{
${ }^{1}$ Changes in tax regulation given in the Tax Reform Act of 1986 allowed REITs to be better managed. The introduction of the umbrella partnership REIT (popularly referred to as UPREIT) at the start of the 1990s was, though, the major propelling factor of growth in the industry mainly because this structure facilitated acquisitions of depressed private real estate properties following the housing market downturn of 1989.
} 
there is a common fundamental factor driving both the securitized and unsecuritized real estate markets. This view is also supported by Geltner (1993), who concludes that both direct and indirect real estate markets have similar long run fundamentals. Han (1991) finds that returns in the underlying unsecuritized real estate market lead REIT returns, while several others including Gyourko and Keim (1992), Liu and Mei (1992) and Barkham and Geltner (1995) find that price discovery happens in the REIT industry before transmitting to the direct real estate market. More recently, the regression analyses performed by Clayton and MacKinnon (2003) and Lee et al. (2010) provide further results that equity REIT returns are very closely linked with the underlying real estate market.

A parallel but entirely separate research program has followed the behavior of prices in the securitized real estate market by investigating whether the market has exhibited "bubble-like" behavior. An early paper by Brooks et al. (2001) applies a variance bound test for bubbles in publicly traded real estate stocks in the UK. Brooks et al. find strong evidence to suggest that there was a bubble in these stocks between 1987 and 1989, as well as from 1996 onwards. Jirasakuldech et al. (2006) test for rational speculative bubbles in equity REIT prices using unit root and co-integration tests. ${ }^{2}$ Hendershott et al. (2003) provide a useful summary of some of the early literature, arguing against the presence of irrational speculative bubbles. The literature on speculative bubbles in the REIT industry is, however, still very limited.

A natural extension to the research that identifies bubbles is to explore whether a bubble in one market leads to a bubble in another, related market. In other words, are bubbles infectious? In the light of the heavily publicized collapse of bubbles in both the housing and stock markets in the late 2000s, this research aims to provide a more detailed analysis of whether speculative bubbles in the REIT market are exacerbated by bubbles in the private market for real estate as well as by bubbles in the equity market. The methods used in this paper could also be used to determine whether there is a multi-directional transmission of speculative bubbles between these markets. Our findings are

\footnotetext{
${ }^{2}$ It is important to note, however, that cointegration tests are poor at detecting bubbles that burst and regenerate (Evans, 1991).
} 
particularly relevant to investors since they could be used to distinguish the different impacts on the REIT market of bubbles in the private market for real estate and the stock market.

Using a regime-switching model, we test for the presence of periodically collapsing bubbles in the equity market and the private and public real estate markets between 1978 and 2012. With an extension of the regime switching model, the paper proceeds to investigate possible bubble spillovers between the markets. The outline of this paper is as follows. Section 2 explains the methods implemented, focusing on the regime switching test used in determining speculative bubble-like behavior in the markets. In Section 3, we provide a detailed description of the sample used in this research. The following section gives an overview of the fundamental measures of the real estate and stock markets. Sections 5 and 6 provide our findings and check for bubble contagion amongst the markets respectively. Finally, in Section 7, we summarize and draw conclusions.

\section{Methodology}

\subsection{The regime-switching bubble model}

We start with the simple observation that the price of a stock $\left(P_{t}^{a}\right)$ today is given by its expected price in the next period plus the income generated from holding that stock in the next period:

$$
P_{t}^{a}=\frac{E_{t}\left(P_{t+1}+D_{t+1}\right)}{(1+i)}
$$

where $D_{t}$ represents the income stream of the asset (e.g. dividends for stocks and rents for real estate), $E_{t}($.$) is the expectation operator and i$ is the discount rate.

In order to test for asset bubbles, it is necessary to determine the fundamental value of the asset. The fundamental price $\left(P_{t}^{f}\right)$, as its name suggests, is influenced solely by market fundamentals and is defined as the sum of the asset's future dividends (or distributed income) discounted to the present time: 


$$
P_{t}^{f}=\sum_{g=1}^{\infty} \frac{E_{t}\left(D_{t+g}\right)}{(1+i)^{g}}
$$

Empirically, the actual asset price often deviates from the fundamental price. These deviations can arise as a result of speculation in the asset's market, where excessive demand by market agents induces price jumps that may exceed the fundamental value of the asset. Hence in the speculative bubble literature, asset prices are split into two separate components, namely the fundamental price and the non-fundamental component (or the bubble component, subject to the conditions discussed in Section 2.2 below), $B_{t}$ :

$$
P_{t}^{a}=P_{t}^{f}+B_{t}+u_{t}
$$

where $u_{t} \sim N\left(0, \sigma^{2}\right)$ is the unexpected innovation of the fundamental and non-fundamental values. The difference between the actual price and the fundamental price in period $t$ is the non-fundamental component.

The first notable bubble model was proposed by Blanchard (1979). This model assumes that there are two possible bubble states: one being a state in which the bubble survives $(S)$ and the other being a collapsing state $(C)$. Blanchard and Watson propose that the bubble process is:

$$
\begin{array}{ll}
E_{t}\left(B_{t+1} \mid S\right)=\frac{(1+i)}{q} B_{t} & \text { with probability } q \\
E_{t}\left(B_{t+1} \mid C\right)=0 & \text { with probability } 1-q
\end{array}
$$

where $q$ is the probability of the bubble surviving and $1-q$ is the probability of a collapse, both in period $t+1 .^{3}$

Equation (4) implies that in period $t+1$, if the bubble does not collapse, the bubble component is expected to grow at a rate higher than the real rate of return. This compensates the investor for risk-

\footnotetext{
${ }^{3}$ Note that the non-fundamentally driven component of price must satisfy equation (1). Therefore, weighted across the surviving and collapsing regimes, this non-fundamental component is expected to grow at the discount rate or the required rate of return.
} 
taking. However, if the bubble collapses, its value diminishes immediately to zero (the collapse of a bubble is not a gradual process) and prices subsequently return to their fundamental value. This model also concludes that the bubble cannot regenerate once it collapses. These are empirically unrealistic conclusions, and van Norden and Schaller $(1993,1999)$ lift these assumptions by modifying the Blanchard and Watson model in two ways. First, they allow the probability of the bubble surviving and continuing to expand to depend on the relative size of the bubble component $\left(b_{t}=B_{t} / P_{t}\right)$, implying that the probability of being in the surviving state falls as the relative size of the bubble grows:

$\frac{\partial q\left(b_{t}\right)}{\partial\left|b_{t}\right|}<0$

The second modification by van Norden and Schaller involves allowing for partial collapses in bubbles, where the size of the bubble gradually decreases in the collapsing state:

$E_{t}\left(B_{t+1} \mid C\right)=u\left(b_{t}\right) P_{t}^{a}$

where $u\left(b_{t}\right)$ is a continuous and everywhere differentiable function:

$0 \leq \frac{\partial u\left(b_{t}\right)}{\partial b_{t}} \leq 1$

Given these two modifications, van Norden and Schaller introduce the modified bubble process:

$$
\begin{array}{ll}
E_{t}\left(B_{t+1} \mid S\right)=\frac{(1+i)}{q\left(b_{t}\right)} B_{t}-\frac{1-q\left(b_{t}\right)}{q\left(b_{t}\right)} u\left(b_{t}\right) \cdot P_{t}^{a} & \text { with probability } q\left(b_{t}\right) \\
E_{t}\left(B_{t+1} \mid C\right)=u\left(b_{t}\right) \cdot P_{t}^{a} & \text { with probability } 1-q\left(b_{t}\right)
\end{array}
$$

Unlike the bubble process in Blanchard and Watson's model, the expected size of the bubble in the collapsing regime is not necessarily equal to zero. But when $u\left(b_{t}\right)$ equals zero and $q\left(b_{t}\right)$ is a constant, $q$, the process reduces to that of Blanchard and Watson. 
Returns to the asset under the van Norden and Schaller bubble specification depend on whether the bubble is in the surviving or collapsing regime, i.e. returns are state dependent. Van Norden and Schaller (1997) propose that the gross return on the asset $(M)$ follows a non-linear switching process: ${ }^{4}$

$$
\begin{array}{ll}
E_{t}\left(R_{t+1} \mid S\right)=\left[M\left(1-b_{t}\right)+\frac{M b_{t}}{q\left(b_{t}\right)}-\frac{1-q\left(b_{t}\right)}{q\left(b_{t}\right)} u\left(b_{t}\right)\right] & \text { with probability } q\left(b_{t}\right) \\
E_{t}\left(R_{t+1} \mid C\right)=M\left(1-b_{t}\right)+u\left(b_{t}\right) & \text { with probability } 1-q\left(b_{t}\right)
\end{array}
$$

Equation (9) shows the gross return of the asset at time $t+1$ depends on the regime in the previous time period. Using a first-order Taylor series approximation method, the model is linearized and estimated. A linear switching regime model for returns is derived with a single state-independent probability of a regime switch, $q\left(b_{t}\right)$ :

$$
\begin{aligned}
& R_{t+1}^{s}=\beta_{s, 0}+\beta_{s, 1} b_{t}+u_{s, t+1} \\
& R_{t+1}^{c}=\beta_{c, 0}+\beta_{c, 1} b_{t}+u_{c, t+1} \\
& P\left(R_{t+1} \mid S\right)=q\left(b_{t}\right)=\Phi\left(\beta_{q, 0}+\beta_{q, 1}\left|b_{t}\right|\right)
\end{aligned}
$$

where the unexpected returns in the collapsing and surviving regimes are represented by $u_{c, t+1}$ and $u_{s, t+1}$ respectively, and they have constant variance and zero mean. $\Phi$ is the standard normal cumulative distribution function and so $\Phi\left(\beta_{q, 0}\right)$ is the probability of being in the surviving regime conditional upon a bubble size of zero, whereas $\beta_{q, 1}$ measures how the probability of being in the surviving regime changes with respect to the absolute bubble size as a proportion of the price. The condition that the probability of the bubble surviving depends inversely on its size as in equation (5) implies that $\beta_{q, 1} \leq 0$.

\footnotetext{
${ }^{4}$ Brooks and Katsaris (2005a, 2005b) also extend the model to allow for abnormal volume to affect the returns in each state and the probability that the bubble will continue to survive. However, given the difficulty in obtaining a comparable measure in the context of direct real estate, we do not implement their augmented model.
} 
Estimation of the parameters in equation (10) is achieved by maximizing the following log-likelihood function, $\ell$ :

$\ell\left(R_{t+1} \mid \xi\right)=\sum_{t=1}^{T} \ln \left[P\left(R_{t+1} \mid S\right) \frac{\phi\left(\frac{R_{t+1}-\beta_{s, 0}-\beta_{s, 1} b_{t}}{\sigma_{s}}\right)}{\sigma_{s}}+\left[1-P\left(R_{t+1} \mid S\right)\right] \frac{\phi\left(\frac{R_{t+1}-\beta_{c, 0}-\beta_{c, 1} b_{t}}{\sigma_{c}}\right)}{\sigma_{c}}\right]$

where $\xi$ represents the set of parameters to be estimated by maximizing the likelihood in (11). The estimated parameters consist of $\beta_{s, 0}, \beta_{s, 1}, \beta_{c, 0}, \beta_{c, 1}, \beta_{q, 0}, \beta_{q, 1}, \sigma_{s}$ and $\sigma_{c}$. Here, the notation $\phi$ represents the standard normal probability density function, $\sigma_{s}$ and $\sigma_{c}$ are the disturbances' standard deviations in the surviving and collapsing regimes respectively.

\subsection{The test for periodically collapsing speculative bubbles}

If periodically collapsing speculative bubbles are present in the asset market, the non-fundamental or bubble model must efficiently predict returns; there are four restrictions on the coefficients that imply that the estimated bubble model is plausible. Firstly, $\beta_{c, 0}$ and $\beta_{s, 0}$ must differ. This means that the average return in the collapsing and surviving bubble regimes must not be the same. Secondly, $\beta_{c, 1}$ must be less than zero, showing that the expected return on the asset is a negative function of the size of the bubble in the collapsing regime. Thirdly, $\beta_{s, 1}$ must be greater than $\beta_{c, 1}$, implying that the return yielded by the bubble is greater in the surviving regime. And finally, $\beta_{q, 1}$ should be less than zero, implying that as the bubble size increases, the probability of being in the surviving regime is expected to fall. Section 5 presents the results for the bubble model's estimated parameters and likelihood ratio tests of the model against the stylized alternatives. 


\section{Data}

For this study, the S\&P 500 Composite index is selected as a proxy for the stock market as it is the consensus choice as a benchmark. Quarterly S\&P 500 real prices and dividends are obtained from Robert Shiller's webpage. ${ }^{5}$ The quarterly data for REITs are obtained from NAREIT. The NAREIT All-REIT index is a market capitalization weighted index calculated from 166 tax-qualified mortgage and equity REITs (as at the second quarter of 2012) that are listed in the NASDAQ, NYSE and AMEX markets.

For the property market, we use the NCREIF Property Index which tracks price increases in commercial real estate prices. It is the longest dated series that focuses on the commercial property market, starting from 1978, and is reported on a quarterly basis. The index has a universe of properties with a market value of $\$ 299$ billion as at the second quarter of 2012 . The property universe comprises apartments, hotels, industrial, office and retail properties, although offices make up a third of the index with apartments and retail outlets around a further quarter each. This index is based on appraised market values and not sales transactions. Appraisers tend to be influenced by historic transaction price observations when valuing properties and so appraisal based indices are likely to have smooth returns, possibly incorporating stale prices. For this paper, we apply the unsmoothing procedure proposed by Geltner (1993). In this method, efficiency is assumed in the commercial real estate market thus the true unsmoothed returns, $r_{t}$, could be recovered from the following autoregressive (AR) model with $p$ lags ( $p$ is assumed to be 4 given that the series is of quarterly frequency) of the smoothed returns, $r_{t}^{*}$ :

$$
r_{t}^{*}=c+\sum_{i=1}^{p} \beta_{i} r_{t-i}^{*}+\varepsilon_{t}
$$

\footnotetext{
${ }^{5}$ Data available at: http://www.econ.yale.edu/ shiller/data.htm.
} 
where $\varepsilon_{t}=\alpha r_{t}, \alpha=2\left(\sigma_{\varepsilon} / \sigma_{M}\right)$, and $\sigma_{\varepsilon}$ and $\sigma_{M}$ are the standard deviations of the error term and of the market (S\&P500) returns respectively, as proposed by Fisher et al. (1994). ${ }^{6}$ The data are all observed quarterly from 1978Q1 to 2012Q1.

\section{Actual prices and fundamentals}

\subsection{Models for estimating fundamental values}

In calculating the fundamental values of stocks and of REITs, we use the dividend multiple approach. Assuming that log dividends follow a random walk with a drift process, van Norden and Schaller (1999) show that the fundamental price of a stock is equal to the average (ex post) price-dividend ratio multiplied by the dividend at the selected time period:

$$
P_{t}^{f}=\frac{\bar{P}}{\bar{D}} D_{t}
$$

and so the non-fundamental or bubble component of the stock is given by simply subtracting the actual price of the stock from its fundamental component, as shown in equation (19):

$$
B_{t}=P_{t}^{a}-\frac{\bar{P}}{\bar{D}} D_{t}
$$

In the case of the direct real estate market, there is no general agreement on the measurement of fundamental house prices. It could be argued that rents would provide a useful measure since, from the real estate investor's point of view, rents are analogous in cash flow terms to dividends for investors in the stock market. However, the house prices we employ are constructed based on data from a variety of sources and as such it is difficult to relate these directly to rents. ${ }^{7}$ Therefore, given the direct influence of several macroeconomic variables on the real estate market, some researchers use a regression-based measure, relating the fundamental value of house prices to disposable incomes, mortgage rates and the level of unemployment. Roche (2001), for example, uses the residual from a

\footnotetext{
${ }^{6}$ Since the parameter estimates from equation (17) are not of direct interest in this study, we do not report them to conserve space.

${ }^{7}$ Xiao and Tan (2007) employ rents as the basis for their fundamental measure. However, cognisant of the difficulty in accurately measuring the fundamental price, they employ a Kalman filter approach to capture possible misspecification or data errors in the model.
} 
regression of house prices on the mortgage rate, disposable income and a demographic variable as a proxy for the non-fundamental price. Similar to Roche, we construct a demand and supply model whereby the direct real estate index is regressed on relevant demand and supply factors. The demand factors include the gross domestic product $(G D P)$, long term interest rate (LTIR), money supply $(M S)$ and term spread (TS) whilst the supply factor used is the labour cost $(L C)$. Gross domestic product is a proxy for economic growth which is expected to have a positive effect on real estate prices. The term spread (the difference between the long and short term interest rates), long term interest rate and money supply are all monetary policy tools which affect the current and future cost of borrowing, thus influencing the demand for commercial real estate investments. Labour cost impacts upon the construction cost of properties, thereby influencing their supply. The regression model is:

$$
N C R E I F_{t}=c+\beta_{1} G D P_{t}+\beta_{2} T S_{t}+\beta_{3} L T I R_{t}+\beta_{4} M 2_{t}+\beta_{5} L C_{t}+e_{t}
$$

The fitted value from this model at each point in time can be referred to as the fundamental index value intrinsically determined by market determinants. Therefore, the model's error term, $e_{t}$, is the part of the index that is not explained by demand and supply factors, thus representing the nonfundamental value of the index.

\subsection{A comparison of actual prices with fundamentals}

A comparison of the observed prices against the fundamental prices (left-hand scale) and the extent of overvaluation as a percentage of the actual price (right-hand scale) are given in Figures 1a-c.

\section{$\langle$ Insert Figures 1a $-\mathrm{c}>$}

There have been periods of over-valuation and under-valuation in all three markets since 1978, especially in the stock market. In parts of the late 1970s and 1980s, stocks traded, on average, below their warranted fundamental values. This was due to the recession of the early 1980s that was caused by counter-inflationary increases in interest rates by the Federal Reserve. From the late 1980s 
onwards, stock prices began to deviate significantly from their fundamental values, as the demand for information technology stocks intensified. The market and price-dividend ratios of many information technology stocks reached unprecedented levels, influencing other sectors. But by 2000 , the market began to free-fall as interest rate increases led to a slowdown in economic activities. The stock market fell by around 55\% between 2000 and 2003, causing the Federal Reserve Board of Governors to respond with sharp cuts in federal funds rate. This helped propel the stock market and prices rose again until 2008. The subprime crisis led to a collapse in lending activities and the bankruptcy of several important financial institutions, and by the end of 2008, stock prices had fallen well below their intrinsic values for the first time since the early 1980s.

In the late 1970s and at the start of 1980s, the commercial property market had been grossly undervalued relative to economic fundamentals. By 1983, property prices began rising above their fundamental values, but this trend halted in 1992 due to the economic recession that followed the Gulf war. From then onwards, the market was undervalued by $8 \%$ on average until 2005Q2. At that time, there was a sudden surge in commercial property prices following the slowdown of the housing market. This boom was short lived however, lasting for just four years compared to the ten years of overvaluation in the 1980s and early 1990s. By 2009, the subprime mortgage crisis, which led to a credit crunch, caused a crash in prices to below fundamentals yet again.

As for the REIT industry, it faced serious difficulties prior to and at the start of our sample period in the 1970s. A large number of mortgage REITs dragged the entire indirect real estate industry into disarray due to the inefficient underwriting of loans and the increasing federal funds rate. There were many bankruptcies and liquidations of REIT firms, causing a crisis of confidence in the industry. During the 1970s, REIT prices were undervalued and neglected by investors. Prices, on average, traded below their intrinsic values until 1991. At the start of the 1992, there was a significant structural change in the industry. The introduction of the UPREIT legislation and the surge in the number of IPOs made the securitized real estate market extremely attractive to investors. Increasing funds allowed REIT managers to be more flexible, investing in a wider range of properties and yielding healthy returns annually. This boom lasted until around 1997, and by 1999, the market had 
dipped back below its fundamental value. However, by the 2000s, the securitized real estate market, began to flourish again. This boom continued and prices accelerated at a faster rate than fundamental values. But by the end of the decade, the residential real estate market downturn began to take its toll on the industry. Between 2007 and 2009, the REIT index value had plummeted by $60 \%$.

\section{Results and Findings}

To determine whether the deviations of the observed prices from their fundamentals described in the previous section were a result of the presence of periodically collapsing speculative bubbles, we apply the regime switching model to returns as discussed in Section 2 and the results from these tests are given in Table 1.

\section{$<$ Insert Table 1 >}

From the table's first panel, there is significant evidence to support the notion that speculative bubbles existed in all three markets. Firstly, a very large proportion of the estimated parameters are statistically significant at the 1 level, implying that the means and volatilities of returns in the two regimes are significantly different. Secondly, from the middle panel, a large proportion of the likelihood ratio tests for the restrictions on the coefficients are statistically significant in all markets. The findings imply that the first regime is one where the bubble survives and continues to grow, yielding a positive return, while the other regime refers to a state where the bubble collapses and prices fall. Realized returns, according bubble theory, should be greater in the surviving bubble regime than the collapsing state. Volatility should be larger, however, in the collapsing bubble state. Lastly, referring to the third panel of the table, the likelihood ratio tests to determine whether the bubble model can explain returns better than other stylized return alternatives such as the volatility regimes, fads and mixture-normal models, provides more evidence that speculative bubbles existed in all three markets. The results show that the van Norden and Schaller bubble model captures returns more efficiently than the stylized alternatives for REITs, and the direct real estate and stock markets. 
The coefficient estimates of the mean returns in the surviving regime $\beta_{s, 0}$ for the direct real estate market, the stock market and the indirect real estate market are 1.61\%, 2.00\% and 2.78\%, respectively. On the other hand, mean quarterly returns in the collapsing regime, $\beta_{c, 0}$, are $-4.54 \%$ (i.e. $1-0.9546)$ for the direct real estate market, $-26.36 \%$ for the stock market, and $-29.67 \%$ for the securitized real estate market. These represent the expected yields in each market when observed prices equal their fundamental values, i.e. there is no bubble. In the three markets, the coefficients on the bubble terms in the surviving regime, $\beta_{s, 1}$, are negative (which is not the expected sign) but they are as expected greater than in the collapsing regime, $\beta_{c, 1}$, implying that the bubble in the collapsing regime yields more negative returns than in the surviving regime. In all the markets, $\beta_{q, 0}$ is greater than zero, which signifies that the probability of being in the surviving regime is positive when there is no bubble. Also, the coefficients of $\beta_{q, 1}$ are less than zero and so that the larger the size of the bubble, the higher the probability of the bubble collapsing in the following period. Given these findings, there is enough evidence to suggest that speculative bubbles led to price deviations from their intrinsic values in all three markets between 1978 and 2012.

\section{$\langle$ Insert Figures 2a $-\mathbf{c}>$}

Figures $2 \mathrm{a}-\mathrm{c}$ provide further evidence of how well the regime-switching bubble model captures returns in the markets. Here, the probability of being in the collapsing regime, $P\left(R_{t+1} \mid C\right)=1-\Phi\left(\beta_{q, 0}+\beta_{q, 1}\left|b_{t}\right|\right)$, is plotted against observed prices using the coefficient estimates from the model. In the direct real estate market, the probability of being in the collapsing regime doubles from $5 \%$ to almost $10 \%$ prior to the downturn of the market in 2008. Similarly, the model fits the stock market's dynamics fairly well, and the probability of collapse rose, along with the growth in the size of the bubble, shortly before the market fell at the end of the 2000s. Also, the probability of a collapse in the REIT market rose shortly before the dip in REIT prices in the 1970s. The probability also rose shortly before the market downturns of the late 1990s and 2006/07. It thus appears that the model is better able to predict collapses than others such as that employed by Xiao 
(2010). We should, however, note that all of the analysis undertaken thus far is in a sense in-sample. At the end of the following section, we examine whether the model was able to produce useful forecasts of the probability of a market collapse in real time.

\section{Are speculative bubbles in the markets contagious?}

Given the above findings in favor of speculative bubbles in the markets, this paper proceeds to investigate possible inter-market transmission of bubbles. This part of the study provides a broader understanding of the relationships between the three markets by investigating whether bubble cycles in the indirect real estate market are influenced by speculative bubbles in the underlying unsecuritized real estate and equity markets or vice-versa. We extend the van Norden and Schaller model by allowing the returns in each of the assets to be dependent on the size of the bubble in its own market and in the other two markets.

In broad terms, contagion can occur when market participants employ information about the performance of one market to infer the likely future behaviour of prices in other markets, even though there may be no new information that is directly relevant to the latter. In this way, bubble growth in one market could be propagated to others, and similarly bubble collapses may occur together. ${ }^{8}$ Entirely the opposite perspective arises from the work of Brounen and Eicholtz (2003). They argue that during the tech-bubble in the stock market, real estate stock prices were depressed as investors preferred to jump on the bandwagon of the bubble in the former, but when the tech bubble collapsed, investors switched to indirect real estate in a flight to safety. Hence at that time, bubble growth and then collapse in the stock market combined with asset class rotation caused precisely the reverse effects in REITs.

We might expect that, owing to its relative illiquidity, high transaction costs, and high minimum investment thresholds, direct real estate might be less prone to speculative bubbles than either securitized real estate or the stock market more broadly. As such, it is possible that REIT and stock market bubbles would be driven by largely the same factors when the behaviour of investors leads

\footnotetext{
${ }^{8}$ See Ghosh et al. (1998) for a discussion of and preliminary tests for contagion between REITs.
} 
actual prices to run away from intrinsic values and thus a bubble in one market could cause nonfundamental price rises in the other. Given that the underlying market prices we employ are appraisal based, it is possible that appraisers will, either consciously or inadvertently, spread a bubble from the REIT or stock markets to the direct market via impounding in their valuations a "feel-good factor" when stock or REIT market bubbles are growing, and a reduction in values when a bubble in these latter markets has burst. Thus it is expectable that bubbles in the underlying real estate market may lag those of the public markets. On the other hand, developing the arguments in Geltner et al. (2003), if appraisers are successful at optimally combining past and current information, they may anticipate the collapse of an overheated REIT or stock market and thus precipitate a prior fall in the direct market, driving valuations downwards in advance of falls in demand.

\subsection{A Model for Bubble Spillovers}

Similar to the approach used by Anderson et. al. (2010) to detect bubble spillover effects between stocks in different industries, we allow for the probability of being in the surviving/collapsing regime to depend not only on its lagged bubble size, but also on the lagged bubble sizes in the other markets:

$$
\begin{aligned}
& R_{t+1}^{s}=\beta_{s, 0}+\sum_{k=1}^{3} \beta_{s, 1, k} b_{t, k}+u_{s, t+1} \\
& R_{t+1}^{c}=\beta_{c, 0}+\sum_{k=1}^{3} \beta_{c, 1, j} b_{t, k}+u_{k, t+1} \\
& P\left(R_{t+1} \mid S\right)=q\left(b_{t, k}\right)=\Phi\left(\beta_{q, 0}+\sum_{j=1}^{3} \beta_{q, 1, k}\left|b_{t, k}\right|\right)
\end{aligned}
$$

Note that $k(k=I R E b, D R E b, S M b)$ denotes the three different markets. Estimation of the parameters of the bubble spillover model (21) are achieved by maximizing the following log-likelihood function: 
$\ell\left(R_{t+1} \mid \xi\right)=\sum_{t=1}^{T} \ln \left[P\left(R_{t+1} \mid S\right) \frac{\left(\frac{R_{t+1}-\beta_{s, 0}-\sum_{k=1}^{3} \beta_{s, 1, k} b_{t, k}}{\sigma_{s}}\right)}{\sigma_{s}}+P\left(R_{t+1} \mid C\right) \frac{\left(\frac{R_{t+1}-\beta_{c, 0}-\sum_{j=1}^{3} \beta_{c, 1, k} b_{t, k}}{\sigma_{c}}\right)}{\sigma_{c}}\right]$

By observing the $p$-values of the coefficient estimates above, inferences on whether speculative bubbles spillover from one market to another may be drawn. The statistical significances of $\beta_{s, 1, k}$, $\beta_{c, 1, k}$, and $\beta_{q, 1, k}$ would imply that the size of one market's bubble influences the returns in the surviving (collapsing) regime or the probability of a collapse in other markets respectively.

\section{< Insert Table 2 >}

Table 2 shows the results from the multivariate bubble model. Overall, it is evident that there is considerable evidence for bubble spillovers despite the large number of parameters estimated and the modest number of quarterly data points. In particular, it is clear from the parameters in the first part of the table that this spillover from real estate to stock market is arising from its usefulness in predicting when the stock market bubble will collapse, and indeed it is noteworthy that all of the parameter estimates in the equations that capture the probability of collapse are statistically significant, indicating that the sizes of the bubbles in each of the markets have a useful role to play in timing when the collapse will occur in the others.

The returns in the surviving regimes for REITs and stock returns are not affected by bubbles in any of the markets, although surviving regime returns in the direct real estate market are significantly influenced by bubbles in all three. On the other hand, returns in the collapsing regime for direct real estate and REITs are both significantly and negatively affected by the size of the bubble in the stock market, $\beta_{C, 1, S M b}$ but not by the indirect real estate market, while the REIT bubble does not affect the returns in the collapsing regime for the stock market but the direct real estate bubble does. In general, 
we can state that there appears to be considerably more connectivity between the asset classes when prices are falling (i.e. in the collapsing regime) than when they are rising (i.e. in the surviving regime), mirroring the widely known stylized fact that correlations between asset returns generally grow during times of market turbulence.

Focusing now on the statistical significance of the estimated coefficients (each of the $\beta_{q, 1}$ ) in the indirect real estate column, there is clear evidence of a speculative bubble spillover from both the underlying direct real estate market and the stock market. An increase in the sizes of the real estate and equity bubbles not only increase the probability of a collapse in their respective markets, but also increase the probability of a collapse in the REIT market (i.e. a reduction in the probability of being in the surviving regime next period). An illustration of this is given numerically: the forecasted probability of the bubble collapsing in the indirect real estate market in the next period is $48.8 \%$, assuming that the stock, direct and indirect real estate markets are all overvalued by $40 \%$. If the bubble size in the stock market relative to prices increases to $60 \%$, ceteris paribus, the forecasted probability of a collapse increases to $53.5 \%$. However, if the relative bubble size of the direct real estate market rises to $60 \%$ while the relative bubble sizes in the other two markets remain unchanged at $40 \%$, the indirect real estate market's forecasted probability of a collapse in the next period only rises by $1.8 \%$ to $50.6 \%$.

The second panel of Table 2 shows the results from likelihood ratio tests of the restrictions that the three parameters relating to the bubble from a specific market do not affect either the returns in the surviving and collapsing regimes or the probability of the bubble collapsing for another market. In other words, this tests the null hypothesis that the true values of each set of $\beta_{s, 1}, \beta_{c, 1}$ and $\beta_{q, 1}$ are all zero at the same time. In a sense, these are akin to Granger causality or block exogeneity tests. The results show that the size of the stock market bubble significantly affects the REIT market bubble (pvalue 0.002 ), while that of the direct property market does not ( $p$-value 0.48$)$. On the other hand, REIT bubbles have a highly significant ( $p$-value 0.0001) effect on bubbles in the direct property market after allowing for bubbles in the other two markets. The sizes of bubbles in both the direct and 
indirect real estate markets have a statistically significant impact on the stock market bubble process. For the period studied, the size of the bubble in the equity market, in particular, negatively (positively) influences the returns in the direct real estate market during bull (bear) states of the market, respectively. This could be explained by capital switching between the two markets - i.e., when the stock market is booming and a positive speculative bubble persists, institutional investors are less interested in the performance of the direct real estate market and so they may reduce their real estate holdings to fund investments in the equity market. The relative size of the equity bubble also has a positive impact on the probability of the underlying commercial real estate bubble surviving, which would subsequently drive prices upwards. A possible explanation for this finding is that whenever there is a growing bubble in the equity market, the aggregate wealth of investors grows. These investors may choose to diversify their portfolios by acquiring actual buildings, thus leading to a rise in the demand for real estate, which could subsequently trigger the inception of a speculative bubble in the property market. Thus, a widening of the stock market bubble may lead the widening of the real estate market bubble, which would subsequently increase the probability of a collapse in the unsecuritized real estate market.

Similarly, the reverse linkage between the direct real estate and the stock markets is found, where the housing bubble influences the survival or collapse of speculative bubbles in the equity market. One major reason why this could be the case is that during periods of speculative bubbles in the housing market, homeowners are more inclined to re-finance their mortgages, and they may re-invest the proceeds in the stock market. This is another form of capital switching between markets. If the amount of money generated from re-mortgaging is large enough to distort the equity market, the prices of stocks may significantly exceed their fundamental values, which may lead to subsequent overheating of the market. Additionally, it may be the case that rising house prices induce a "feel good factor" among home owners that increases the confidence of consumers to make large purchases, thus increasing corporate profits and putting upward pressure on stock valuations.

Although the number of parameters in the bubble spillover model makes it difficult to interpret the individual estimates precisely, a key point to note is the multi-directional flow of bubbles between the 
real estate and equity markets. The implications of the findings are relevant to investors, especially those whose portfolios are REIT stock-biased. Such investors may be able to form profitable REIT trading strategies or to time the market to avoid likely bubble collapses based on forecasts of the overvaluation in the underlying property and equity markets.

In order to investigate how well the model performs around the post-2000 era of sub-prime and credit crises, and also to examine whether it is capable of producing accurate real time forecasts of the probability of the bubble collapsing, we now replicate the results of Table 2 but this time using only data up to and including 2000Q4. The results are presented in Table 3. The parameter estimates for the REIT equation only are presented, to avoid repetition and since this is the key focus of our study, and show that the results are qualitatively very similar to those for the whole sample period. The second panel of Table 3 shows that for this early sub-period, there is evidence of a spillover from the direct real estate bubble to the REIT one whereas for the entire sample there is not.

\section{$\langle$ Insert Table 3>}

While Figure 2(a) is able to demonstrate the usefulness of the model in timing bubble collapses (the probability of being in the collapsing regime rises substantially before many significant price falls), these results should be interpreted with caution, since they are effectively in-sample, using all the data ex post to estimate the probabilities of being in each regime. Figure 3, by contrast (again focusing on the REIT market only), plots the probability of being in the collapsing regime from a recursive estimation where the estimates are determined using data to $2000 \mathrm{Q} 4$ only and then the sample is updated one quarter at a time with a forecast of the probability calculated for the following quarter. It is clear that the key features of Figure 3 remain, and the model is able to produce useful out of sample predictions of the probability of being in the collapsing regime during the next quarter.

\section{< Insert Figure 3>}

\section{Summary and Conclusions}


With the use of a regime-switching bubble model of returns, this paper finds that periodically collapsing positive and negative bubbles persist in the stock, direct and indirect real estate markets between 1978 and 2012. We employ likelihood ratio tests to show that the bubble model fares better in predicting returns than other stylized alternative models such as the fads, volatility regime and mixture-normal models, providing proof that periods of under- and over-valuation in the markets were fuelled by investors' speculative behavior. We also show how the estimated probability of a collapse in the next period significantly increases as the bubble size increases the markets.

Due to the lack of consensus in the literature regarding the linkage between the equity, direct and indirect real estate markets, the paper proceeds to further investigate the relationship by examining whether speculative bubbles in the markets were contagious. The question here is whether increases in any of the markets' bubbles spurred an increase in the probability of a collapse in another market. Focusing on the impact of speculative bubbles in the direct real estate and the equity markets, we find that there is a spillover of stock market bubbles to the securitized real estate market. The underlying real estate bubble, however, has a weaker effect than the stock bubble on the REIT bubble. In addition, we find the transmission of speculative bubbles to be multi-directional - i.e., there is a reciprocal spillover relationship between the indirect real estate market and the stock market, providing an indication of possible capital switching between these sectors. Finally, we observe that bubbles spill over from real estate (direct and indirect) to equities but returns do not.

Our findings could be useful to investors, as they could potentially use the forecasted probability of a collapse or a crash in the equity and real estate markets to form profitable trading rule for REIT stocks in a multivariate extension of the trading rules proposed by Brooks and Katsaris (2005a). In addition, the findings from this paper may be relevant to regulators and policymakers, since it is possible that they could more accurately evaluate the likelihood of a collapse in any of the markets, at any given time. For example, it may be possible to predict the probability of switching to a collapsing regime in the stock market by observing the degree of over-valuation in the direct real estate market. This sort of early warning of a high probability of a collapse combined with a better knowledge of the interlinkages between bubbles in the underlying, indirect and stock markets could assist policymakers 
in forming decisions that may possibly avert a complete and simultaneous collapse in both the stock and the real estate markets as occurred in the late 2000s. However, additional research would be required to evaluate the strength and efficacy of these early signals from a policy perspective.

This study also sets a potential path for further academic research. Given the findings of the paper, future work may investigate how long it takes for speculative bubbles in any given market to filter into other markets and for how long the impact persists. Furthermore, one could also examine whether it is possible to create a dynamic portfolio mix of the three assets that is based on forecasting the probabilities of collapses in each market.

\section{REFERENCES}

Anderson, K., Brooks, C. and Katsaris, A. (2010) Speculative bubbles in the S\&P 500: Was the tech bubble confined to the tech sector?, Journal of Empirical Finance, 17(3), pp. 345 - 361.

Barkham, R. and Geltner, D. (1995) Price discovery in American and British property markets, Real Estate Economics, 23, pp. 21-44.

Blanchard, O.J. (1979) Speculative bubbles, crashes and rational expectations, Economics Letters, 3, pp. 387-389.

Brounen, D. and Eichholtz, P. (2003) Property, common stock and property shares, Journal of Portfolio Management, 28(3), pp. 129-137.

Brooks, C. and Katsaris, A. (2005a) Trading rules from forecasting the collapse of speculative bubbles for the S\&P 500 composite index, Journal of Business, 78(5), pp. 2003-2036.

Brooks, C. and Katsaris, A. (2005b) A Three-Regime Model of Speculative Behaviour: Modelling the Evolution of Bubbles in the S\&P 500 Composite Index, Economic Journal 115, pp. 767-797.

Brooks, C., Katsaris, A., McGough, T. and Tsolacos, S. (2001) Testing for bubbles in indirect property price cycles., Journal of Property Research, 18, pp. 1-19.

Chan, S.H., Leung, W. K. and Wang, K. (1998) Institutional Investment in REITs: Evidence and Implications, Journal of Real Estate Research, 16, pp. 357-374. 
Clayton, J. and MacKinnon, G. (2003) The relative importance of stock, bond and real estate factors in explaining REIT returns, Journal of Real Estate Finance and Economics, 27(1), pp. 39-60.

Davis, M.A. and Lehnert, A., and Robert, F.M. (2008) The rent-price ratio for the aggregate stock of owner-occupied housing, Review of Income and Wealth, 54(2), pp. 279-284.

Ewing, B.T., Payne, J.E. (2005) The response of real estate investment trust returns to macroeconomic shocks, Journal of Business Research, 58 (3), pp. 293-300.

Fisher, J., Geltner, D., and Webb, B., 1994) Value indices of commercial real estate: a comparison of index construction methods, Journal of Real Estate Finance and Economics 9(2), pp. 137-164.

Geltner, D. (1993) Estimating market values from appraised values without assuming market efficiency, Journal of Real Estate Research, 8(3), pp. 325-346.

Geltner, D., MacGregor, B.D., and Schwann, G.M. (2003) Appraisal smoothing and price discovery in real estate markets, Urban Studies, 40(5-6), pp. 1047-1064.

Ghosh, C., Guttery, R.S., and Sirmans, C.F. (1998) Contagion and REIT stock prices, Journal of Real Estate Research, 16(3), pp. 389-400.

Giliberto, S. M. (1990) Equity real estate investment trusts and real estate returns, Journal of Real Estate Research, 5, pp. 259-64.

Glascock, J., Lu, C. and So, R. (2000) Further evidence on the integration of REIT, bond and stock returns, Journal of Real Estate Finance and Economics, 20, pp. 177-194.

Goetzmann, W.N. and Ibbotson, R.G. (1990) The performance of real estate as an asset class, Journal of Applied Corporate Finance, 3, pp. 65-76.

Gyourko, J., and Keim, D. B. (1993) Risk and return in real estate: evidence from a real estate stock index, Financial Analysts Journal, 49, pp. 39-46.

Gyourko, J., and Keim, D. B. (1992) What does the stock market tell us about real estate returns? Journal of the American Real Estate and Urban Economics Association, 20, pp. 457-485.

Han, J. (1990) The return-generating process of Real Estate Investment Trusts, Working paper, Massachusetts Institute of Technology.

Hendershott, P.H., Hendershott, R.J. and Ward, C.W.R. (2003) Corporate Equity and Commercial Property Market ‘Bubbles’, Urban Studies, 40(5-6), pp. 993-1009. 
Jirasakuldech, B., Campbell, R. and Knight, J. (2006) Are there rational speculative bubbles in REITs?, Journal of Real Estate Finance and Economics, 32, pp. 105-107.

Lai, R.N. and Van Order, R.A. (2010) Momentum and house price growth in the United States: Anatomy of a bubble, Real Estate Economics, 38, pp. 753 - 773.

Laopodis, N. (2009) REITs, the stock market and economic activity. Journal of Property Investment and Finance, 27, pp. 563-578.

Lee, M-L. and Chiang, K. (2010) Long-run price behaviour of equity REITs: become more like common stocks after the early 1990s? Journal of Property Investment \& Finance, 28(6), pp. $454-465$.

Liu, C., and Mei, J. (1992) The predictability of returns on equity REITs and their co-movement with other assets, Journal of Real Estate Finance and Economics, 5, pp. 401-418.

Okunev, J. and Wilson, P. (1997) Using nonlinear tests to examine integration between real estate stock markets, Real Estate Economics, 25(3), pp. 487-503.

Okunev, J., Wilson, P. and Zurbruegg, R. (2000) The causal relationship between real estate and stock markets, Journal of Real Estate Finance and Economics, 21, pp. 251-61.

Payne, J. and Waters G. (2007) Have equity REITs experienced periodically collapsing bubbles?, Journal of Real Estate Finance and Economics 34(2), pp. 207-224.

Roche, M.J. (2001) The rise in house prices in Dublin: bubble, fad or just fundamentals, Economic Modelling 18, pp. $281-295$.

Seiler, M. J., Webb, J. R. and Myer, F. C. N. (1999) Are EREITs real estate?, Journal of Real Estate Portfolio Management, 1999, 5, pp. 171-82.

Simon, S. and Ng, W.L. (2009) The effect of the real estate downturn on the link between REITs and the stock market, Journal of Real Estate Portfolio Management, 15, pp. 211-219.

Van Norden S. and Schaller H. (1993) The predictability of stock market regime: Evidence from the Toronto Stock Exchange, Review of Economics and Statistics, 75(3), pp. 505-510.

Van Norden S. and Schaller H. (1999) Speculative behaviour, regime-switching, and stock market crashes, Nonlinear Time Series Analysis of Economic and Financial Data, Philip Rothman ed., pp. 321-356. 
Xiao, Q. (2010) Crashes in Real Estate Prices: Causes and Predictability, Urban Studies, 47(8), pp. $1725-1744$.

Xiao, Q. and Tan, G.K.R. (2007) Signal Extraction with Kalman Filter: A Study of the Hong Kong Property Price Bubbles, Urban Studies, 44(4), pp. 865-888.

TABLE 1: Results from the van Norden and Schaller speculative bubble model

$$
\begin{aligned}
& R_{t+1}^{s}=\beta_{s, 0}+\beta_{s, 1} b_{t}+u_{s, t+1} \\
& R_{t+1}^{c}=\beta_{c, 0}+\beta_{c, 1} b_{t}+u_{c, t+1} \\
& P\left(R_{t+1} \mid S\right)=q\left(b_{t}\right)=\Phi\left(\beta_{q, 0}+\beta_{q, 1}\left|b_{t}\right|\right)
\end{aligned}
$$

\begin{tabular}{|c|c|c|c|}
\hline Parameters & Indirect real estate market & Direct real estate market & Stock Market \\
\hline$\beta_{s, 0}$ & 1.0278 & 1.0161 & 1.0200 \\
& $(0.0000)$ & $(0.0000)$ & $0.0000)$ \\
\hline$\beta_{s, 1}$ & -0.0251 & -0.0307 & $(0.6450)$ \\
\hline$\beta_{c, 0}$ & $(0.5040)$ & $(0.0054)$ & 0.7364 \\
& 0.7033 & 0.9546 & $(0.0000)$ \\
\hline$\beta_{c, 1}$ & $(0.0000$ & $(0.0000)$ & -0.1872 \\
& -0.2583 & -0.1300 & $(0.0000)$ \\
\hline$\beta_{q, 0}$ & $(0.0000)$ & $(0.0000)$ & 2.1073 \\
& 2.3546 & 1.8356 & $(0.0000)$ \\
\hline$\beta_{q, 1}$ & $(0.0002)$ & $(0.0000)$ & -0.3126 \\
& -0.9550 & -3.0525 & $(0.8364)$ \\
\hline$\sigma_{s}$ & $(0.6412)$ & $(0.1397)$ & 0.0137 \\
& 0.0102 & 0.00060 & $(0.0000)$ \\
\hline$\sigma_{c}$ & $(0.7682)$ & $(0.0000)$ & 0.0545 \\
\end{tabular}

LIKELIHOOD RATIO TEST OF RESTRICTIONS

\begin{tabular}{|c|c|c|c|c|c|c|}
\hline & \multicolumn{2}{|c|}{ Indirect real estate market } & \multicolumn{2}{c|}{ Direct real estate market } & \multicolumn{2}{c|}{ Stock Market } \\
\hline Restrictions & Test statistics & $\mathrm{p}$-values & Test statistics & $\mathrm{p}$-values & Test statistics & $\mathrm{p}$-values \\
\hline$\beta_{s, 0} \neq \beta_{c, 0}$ & 15.9538 & 0.0001 & 13.7063 & 0.0002 & 17.9054 & 0.0000 \\
\hline$\beta_{c, 1}<0$ & 38.0381 & 0.0000 & 8.1850 & 0.0042 & 5.5209 & 0.0188 \\
\hline$\beta_{s, 1}>\beta_{c, 1}$ & 38.4521 & 0.0000 & 7.4064 & 0.0065 & 5.7116 & 0.0169 \\
\hline$\beta_{q, 1}<0$ & 0.1965 & 0.6576 & 1.1404 & 0.2856 & 0.0434 & 0.8349 \\
\hline
\end{tabular}

BUBBLE MODEL SPECIFICATION TEST AGAINST STYLISED ALTERNATIVE MODELS

\begin{tabular}{|c|c|c|c|c|c|c|}
\hline \multirow{2}{*}{} & \multicolumn{2}{|c|}{ Indirect real estate market } & \multicolumn{2}{c|}{ Direct real estate market } & \multicolumn{2}{c|}{ Stock Market } \\
\cline { 2 - 7 } & Test statistics & p-values & Test statistics & p-values & Test statistics & p-values \\
\hline Fads & 35.0257 & 0.0000 & 55.9040 & 0.0000 & 22.1235 & 0.0001 \\
\hline Mixture-normal & 38.2348 & 0.0000 & 61.8140 & 0.0000 & 22.3294 & 0.0001 \\
\hline Volatility regime & 35.0318 & 0.0000 & 56.2452 & 0.0000 & 18.6911 & 0.0009 \\
\hline
\end{tabular}


This table provides results from the tests for speculative bubbles in all three markets. The figures in parentheses represent the $p$-values of the parameter estimates which are computed by taking the inverse of the Hessian matrix. The likelihood ratio test is of the four restrictions implied by the bubble model while the specification test checks whether other stylized alternative models explain returns better than the regime-switching bubble model.

TABLE 2: Results from the bubble spillover model 1978Q1-2012Q1

$$
\begin{aligned}
& R_{t+1, j}^{s}=\beta_{s, 0}+\sum_{j=1}^{3} \beta_{s, 1, j} b_{t, j}+u_{s, t+1} \text { where } j=I R E b, D R E b, S M b \\
& R_{t+1, j}^{c}=\beta_{c, 0}+\sum_{j=1}^{3} \beta_{c, 1, j} b_{t, j}+u_{c, t+1} \\
& P\left(R_{t+1, j} \mid S\right)=q\left(b_{t, j}\right)=\Phi\left(\beta_{q, 0}+\sum_{j=1}^{3} \beta_{q, 1, j}\left|b_{t, j}\right|\right)
\end{aligned}
$$

\begin{tabular}{|c|c|c|c|}
\hline \multicolumn{4}{|c|}{ Dependent variables } \\
\hline Parameters & Indirect real estate market & Direct real estate market & Stock market \\
\hline$\beta_{S, 0}$ & $\begin{array}{c}1.0332 \\
(0.0000)\end{array}$ & $\begin{array}{c}1.0161 \\
(0.0000)\end{array}$ & $\begin{array}{c}1.0096 \\
(0.0000)\end{array}$ \\
\hline$\beta_{S, 1, I R E b}$ & $\begin{array}{l}0.0305 \\
(0.4420)\end{array}$ & $\begin{array}{c}0.0400 \\
(0.0000)\end{array}$ & $\begin{array}{c}0.0022 \\
(0.3414)\end{array}$ \\
\hline$\beta_{S, 1, D R E b}$ & $\begin{array}{l}-0.0512 \\
(0.2692) \\
\end{array}$ & $\begin{array}{l}-0.0096 \\
(0.0000) \\
\end{array}$ & $\begin{array}{c}0.0292 \\
(0.9353) \\
\end{array}$ \\
\hline$\beta_{S, 1, S M b}$ & $\begin{array}{l}-0.0608 \\
(0.1205)\end{array}$ & $\begin{array}{l}-0.0073 \\
(0.0013)\end{array}$ & $\begin{array}{c}0.0412 \\
(0.2595)\end{array}$ \\
\hline$\beta_{C, 0}$ & $\begin{array}{c}0.9364 \\
(0.0000)\end{array}$ & $\begin{array}{c}0.9713 \\
(0.0000)\end{array}$ & $\begin{array}{c}0.9236 \\
(0.0000)\end{array}$ \\
\hline$\beta_{C, 1, I R E b}$ & $\begin{array}{l}-0.1923 \\
(0.0375) \\
\end{array}$ & $\begin{array}{c}0.0257 \\
(0.2787) \\
\end{array}$ & $\begin{array}{l}-0.1161 \\
(0.2321) \\
\end{array}$ \\
\hline$\beta_{C, 1, D R E b}$ & $\begin{array}{l}-0.2605 \\
(0.0000)\end{array}$ & $\begin{array}{l}-0.0805 \\
(0.0072)\end{array}$ & $\begin{array}{l}-0.0722 \\
(0.0000)\end{array}$ \\
\hline$\beta_{C, 1, S M b}$ & $\begin{array}{c}0.4358 \\
(0.0287)\end{array}$ & $\begin{array}{c}0.0719 \\
(0.0000)\end{array}$ & $\begin{array}{l}-0.2701 \\
(0.0000)\end{array}$ \\
\hline$\beta_{q, 0}$ & $\begin{array}{r}3.3630 \\
(0.0001) \\
\end{array}$ & $\begin{array}{c}0.5813 \\
(0.0506) \\
\end{array}$ & $\begin{array}{c}2.1657 \\
(0.0000) \\
\end{array}$ \\
\hline$\beta_{q, 1, I R E b}$ & $\begin{array}{l}-7.5084 \\
(0.0218) \\
\end{array}$ & $\begin{array}{l}-1.2094 \\
(0.0000)\end{array}$ & $\begin{array}{l}-0.7534 \\
(0.0042)\end{array}$ \\
\hline$\beta_{q, 1, D R E b}$ & $\begin{array}{l}-0.2271 \\
(0.0180)\end{array}$ & $\begin{array}{l}-1.1849 \\
(0.0000)\end{array}$ & $\begin{array}{c}0.7684 \\
(0.0743)\end{array}$ \\
\hline$\beta_{q, 1, S M b}$ & $\begin{array}{l}-0.5960 \\
(0.0000)\end{array}$ & $\begin{array}{c}0.3127 \\
(0.0000)\end{array}$ & $\begin{array}{l}-3.1887 \\
(0.0194)\end{array}$ \\
\hline$\sigma_{S}$ & $\begin{array}{c}0.0615 \\
(0.0000) \\
\end{array}$ & $\begin{array}{c}0.0095 \\
(0.0000) \\
\end{array}$ & $\begin{array}{c}0.0495 \\
(0.0000) \\
\end{array}$ \\
\hline$\sigma_{C}$ & $\begin{array}{c}0.0734 \\
(0.0034)\end{array}$ & $\begin{array}{c}0.0142 \\
(0.0000)\end{array}$ & $\begin{array}{c}0.0507 \\
(0.0027)\end{array}$ \\
\hline \multicolumn{4}{|c|}{ BLOCK EXOGENEITY TESTS FOR BUBBLE SPILLOVERS } \\
\hline \multirow{2}{*}{ SPILLOVER FROM: } & \multicolumn{3}{|c|}{ DEPENDENT MARKET } \\
\hline & Indirect real estate market & Direct real estate market & Stock market \\
\hline Indirect real estate bubble & - & $\begin{array}{l}20.4098 \\
(0.0001)\end{array}$ & $\begin{array}{l}18.0935 \\
(0.0004)\end{array}$ \\
\hline Direct real estate bubble & $\begin{array}{c}2.5431 \\
(0.4767)\end{array}$ & - & $\begin{array}{l}18.3528 \\
(0.0003)\end{array}$ \\
\hline Stock market bubble & $\begin{array}{l}14.9540 \\
(0.0019)\end{array}$ & $\begin{array}{c}5.7652 \\
(0.1236)\end{array}$ & - \\
\hline
\end{tabular}


Here, IREb, DREb and $S M b$ refer to the bubbles in the indirect real estate, direct real estate and stock markets, respectively. The block exogeneity tests provide evidence on whether there is contagion of bubbles from one market to another. Here, the specification test checks whether other stylized alternative models explain returns better than the regime-switching bubble model. Note that the $p$-values are obtained by computing the diagonal of the Hessian matrix's inverse and they are the numbers in the parentheses. The shaded boxes denote estimates that are significant at the $10 \%$ level or better.

TABLE 3: REIT bubble spillover forecast model estimated using data 1978Q1-2000Q4 only $R_{t+1, R E I T}^{s}=\beta_{s, 0}+\sum_{j=1}^{3} \beta_{s, 1, j} b_{t, j}+u_{s, t+1} \quad$ where $j=I R E b, D R E b, S M b$ $R_{t+1, R E I T}^{c}=\beta_{c, 0}+\sum_{j=1}^{3} \beta_{c, 1, j} b_{t, j}+u_{c, t+1}$ $P\left(R_{t+1, R E I T} \mid S\right)=q\left(b_{t, j}\right)=\Phi\left(\beta_{q, 0}+\sum_{j=1}^{3} \beta_{q, 1, j}\left|b_{t, j}\right|\right)$

\begin{tabular}{|c|c|}
\hline Parameters & $\begin{array}{c}\text { Estimates } \\
\text { (standard errors) }\end{array}$ \\
\hline$\beta_{S, 0}$ & $\begin{array}{c}1.0305 \\
(0.0000)\end{array}$ \\
\hline$\beta_{S, 1, I R E b}$ & $\begin{array}{c}0.1507 \\
(0.0671)\end{array}$ \\
\hline$\beta_{S, 1, D R E b}$ & $\begin{array}{l}-0.1041 \\
(0.1176)\end{array}$ \\
\hline$\beta_{S, 1, S M b}$ & $\begin{array}{c}0.0336 \\
(0.3172)\end{array}$ \\
\hline$\beta_{C, 0}$ & $\begin{array}{c}1.1333 \\
(0.0000)\end{array}$ \\
\hline$\beta_{C, 1, I R E b}$ & $\begin{array}{l}-0.4527 \\
(0.0149)\end{array}$ \\
\hline$\beta_{C, 1, D R E b}$ & $\begin{array}{l}-0.2589 \\
(0.0026)\end{array}$ \\
\hline$\beta_{C, 1, S M b}$ & $\begin{array}{l}-0.8088 \\
(0.0027)\end{array}$ \\
\hline$\beta_{q, 0}$ & $\begin{array}{l}3.5256 \\
(0.0455)\end{array}$ \\
\hline$\beta_{q, 1, I R E b}$ & $\begin{array}{l}-6.8653 \\
(0.1435)\end{array}$ \\
\hline$\beta_{q, 1, D R E b}$ & $\begin{array}{l}-1.6381 \\
(0.0307)\end{array}$ \\
\hline$\beta_{q, 1, S M b}$ & $\begin{array}{l}-0.1900 \\
(0.3041)\end{array}$ \\
\hline$\sigma_{S}$ & $\begin{array}{c}0.0494 \\
(0.0000)\end{array}$ \\
\hline$\sigma_{C}$ & $\begin{array}{c}0.0525 \\
(0.0000)\end{array}$ \\
\hline \multicolumn{2}{|c|}{ BLOCK EXOGENEITY TESTS FOR BUBBLE SPILLOVERS } \\
\hline SPILLOVER FROM: & Dependent Market: REIT market \\
\hline REIT bubble & - \\
\hline Direct real estate bubble & $\begin{array}{l}20.8648 \\
(0.0000)\end{array}$ \\
\hline Stock market & $\begin{array}{c}6.6878 \\
(0.0825)\end{array}$ \\
\hline
\end{tabular}


Figure 1: Actual Price, Fundamental Value and the relative bubble size (1978Q1 2012Q1)

(a) The Direct Real Estate Market

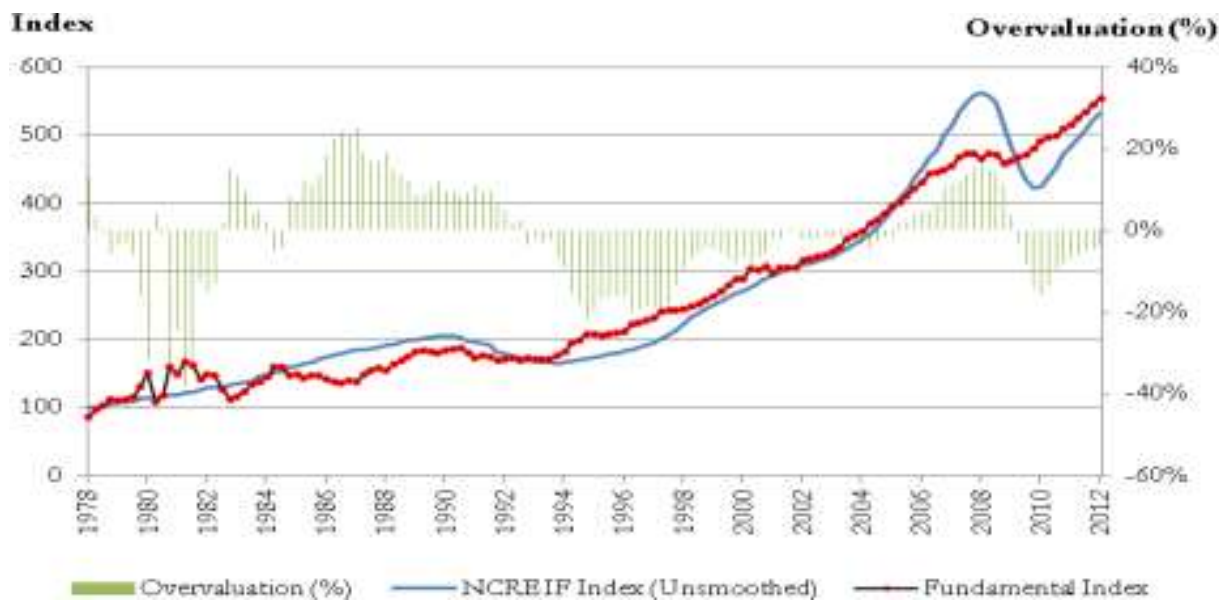

(b) The Indirect Real Estate Market

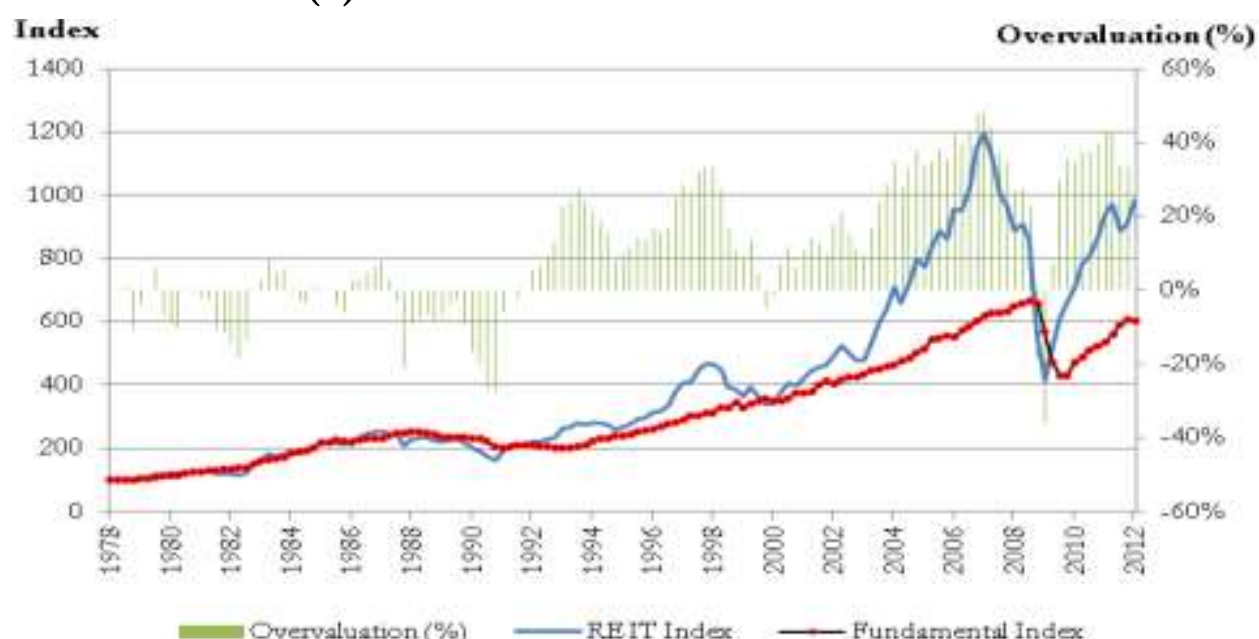

(c) The Stock Market 


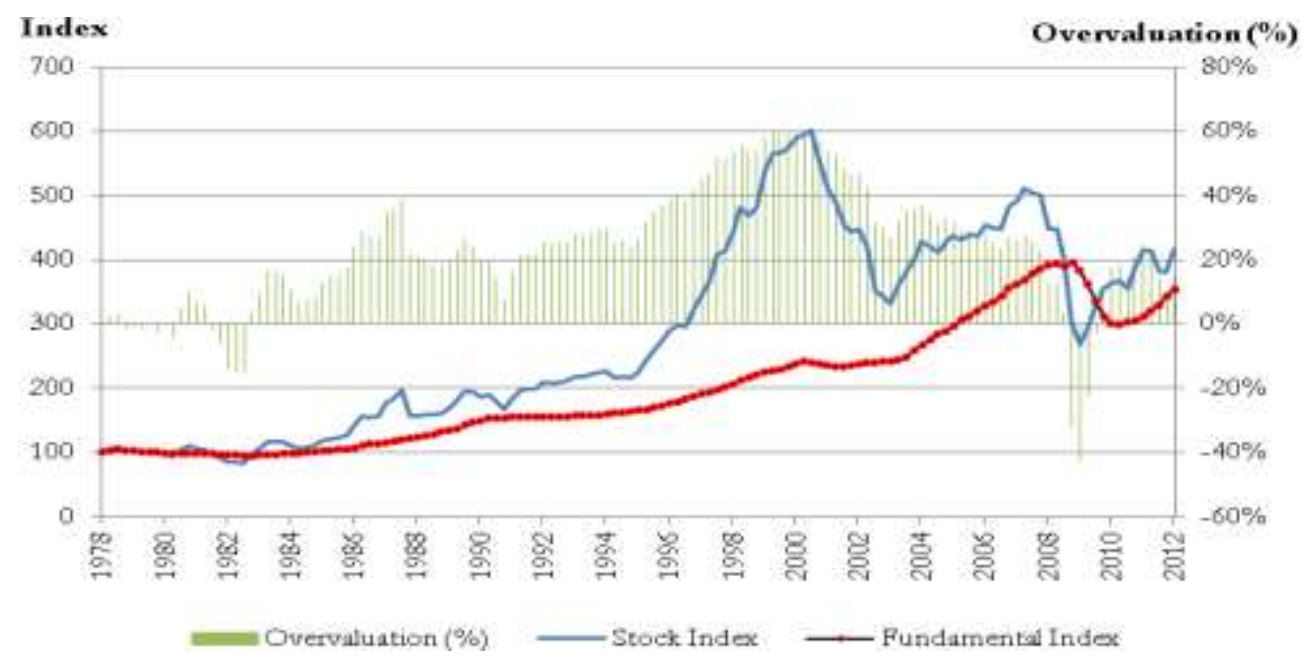

FIGURE 2: The probability of switching to the collapsing regime plotted against the actual and fundamental price series (1978Q1 - 2012Q1)

(a) The Direct Real Estate Market

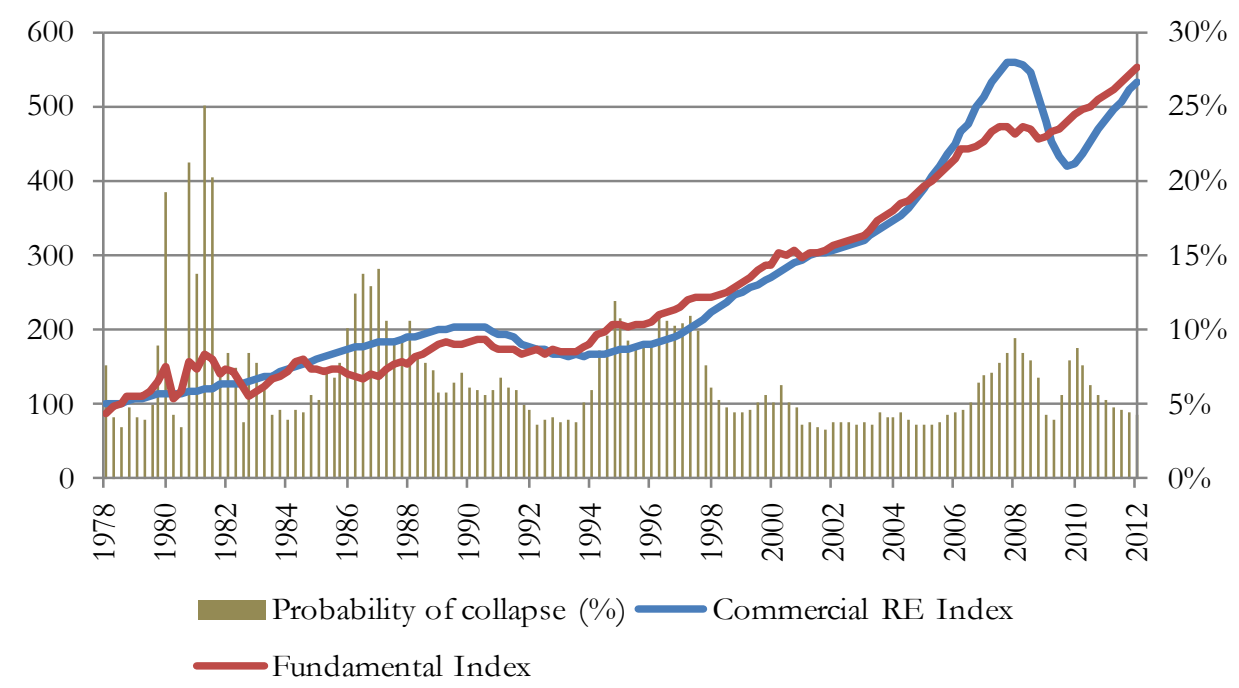

(b) The Indirect Real Estate Market

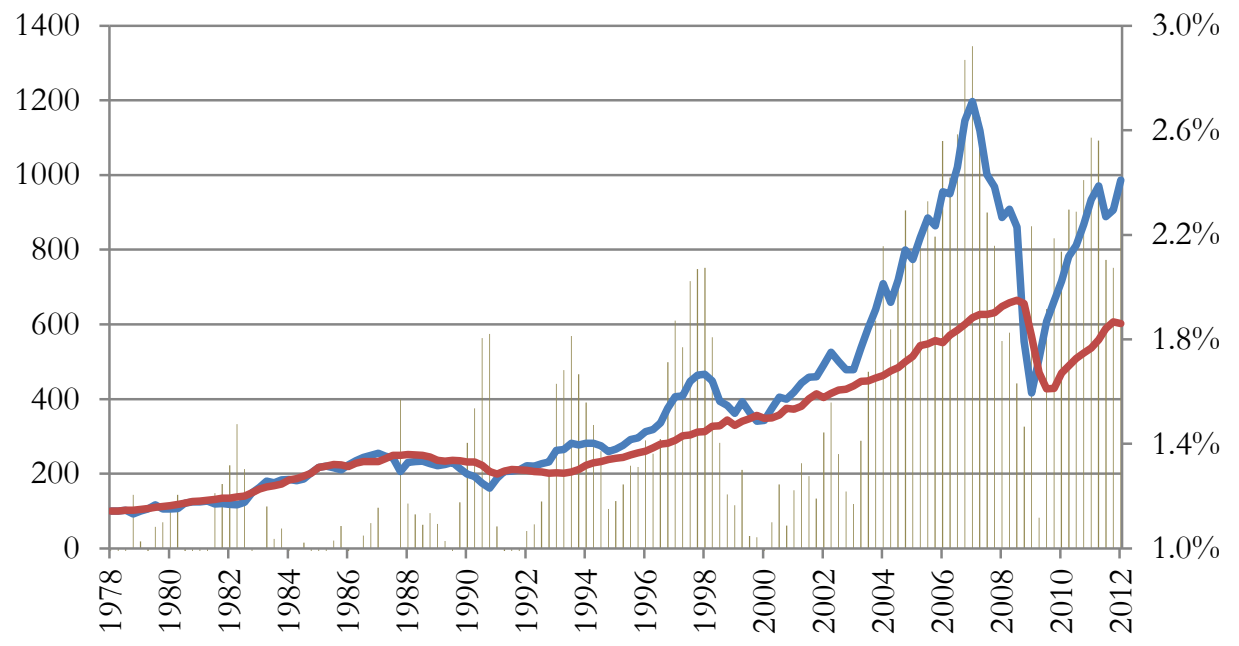

Probability of collapse $(\%) \quad$ REIT Index $\quad$ Fundamental Index 
(c) The Stock Market

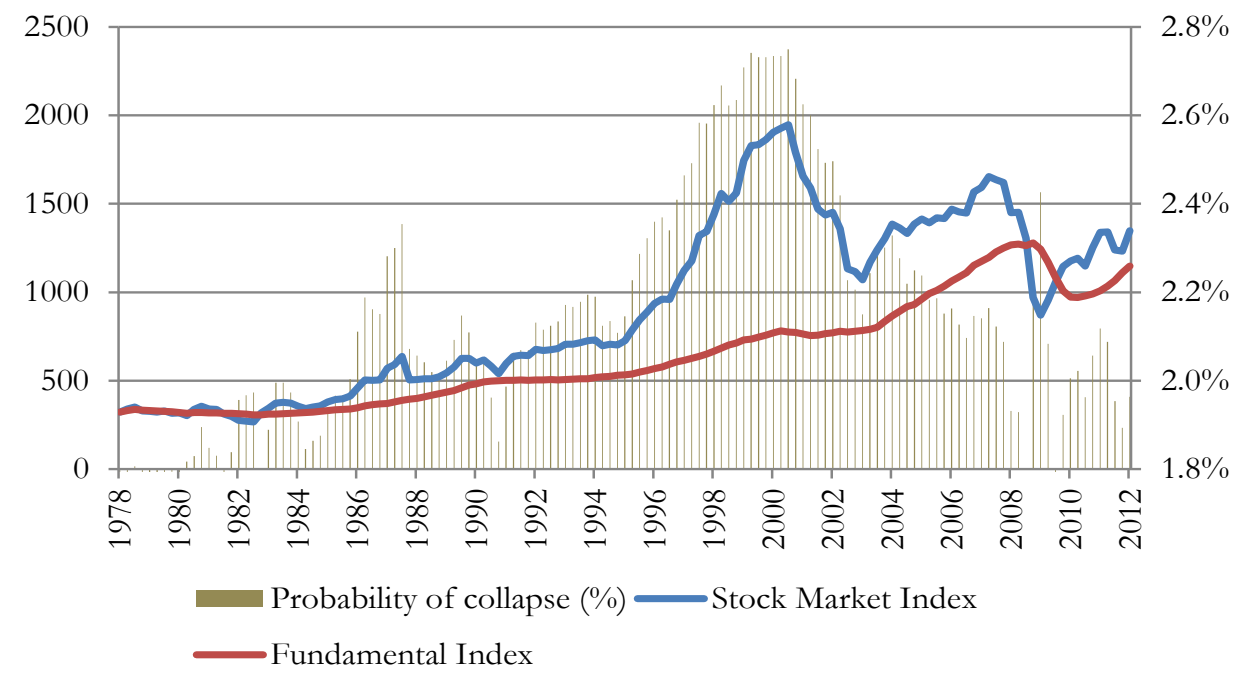

FIGURE 3: The probability of switching to the collapsing regime plotted against the actual and fundamental price series from a model estimated 1978Q1-2000Q4 with 1-step ahead rolling probabilities forecasted thereafter

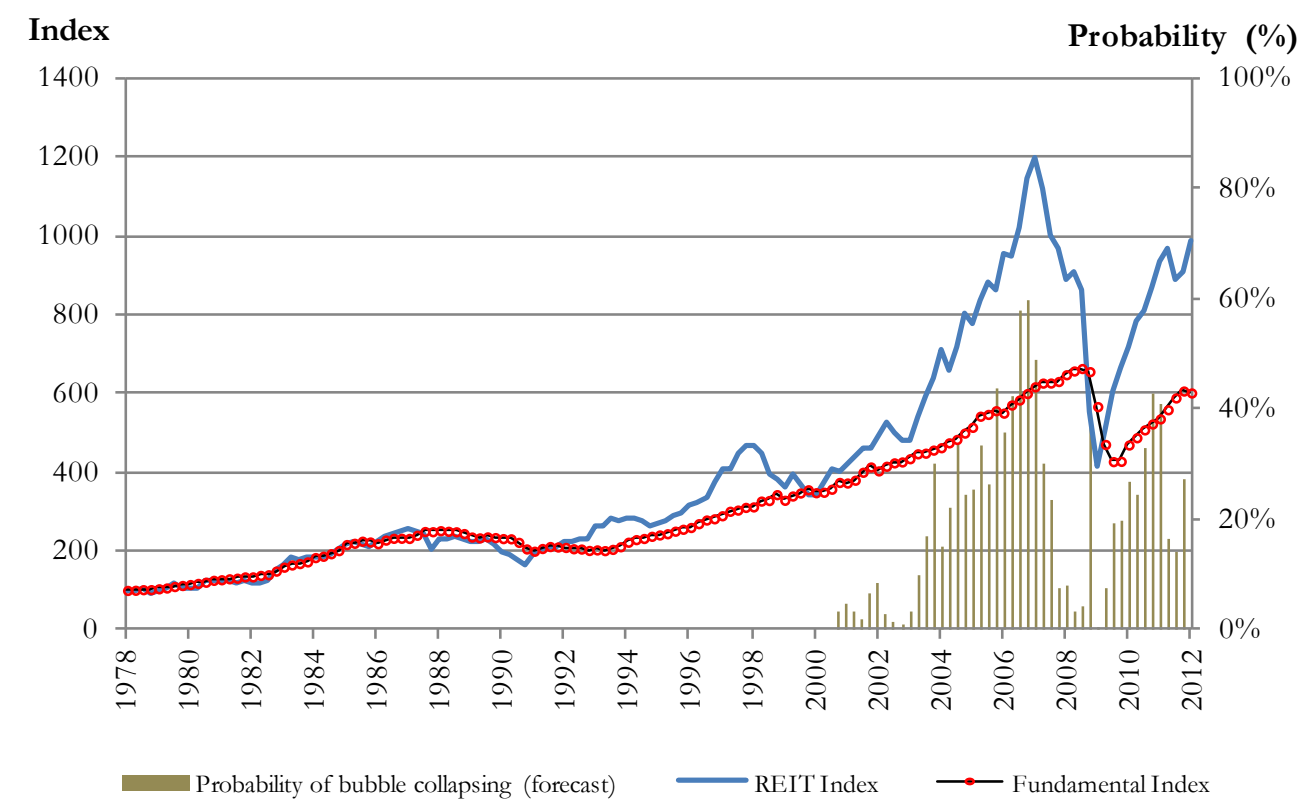

